\title{
Improvement in Animal Production: Animal Health
}

\author{
$B Y$ \\ K. A. O. SANSI. \\ Deputy: Director, \\ Federal Department of Veterinary Research, \\ Vom.
}

\section{INTRODUCTION}

THE state of health of an animal is crucial to its productivity either in the form of food conversion to put on flesh or in the production of milk or in the reproduction of young ones. A state of deviation from normal health is called disease. Many factors are responsible for the causation of disease, namely -- physical, chemical, nutritional, management, bacterial, viral and parasitic agents. Seme of these factors are interrelated in the establishment or in prevention of disease. Broadly speaking, a well-fed animal kept in a hygenic surrounding is more likely to resist infection by bacteria. On the other hand, overnutrition as well as undernutrition may cause degenerative changes in the body (Sansi, 1974). Previous speakers have already dealt in detail with roles of management, breeding and nutrition in the improvement of livestock production and I do not wish to belabour you any further on these subjects other than to say that they are important when discussing role of animal health in the improvement in animsl production.

\section{ANIMAL HEALTH INSTITUTIOONS IN NIGERIA}

The history of organised attempt to cater for animal heath in livestock population can be traced back to 1914 when the first two Veterinary Surgeons were appointed by the then colonial government
(Marshall). The veterinarians were located in Zaria where the animal diseases control policy to be adopted was evolved. Decisions were also taken on the professional staff complement required to implement the policy and the establishment of a laboratory at Vom to produce required biologicals. Between 1924 and 1925 , the small veterinary establishment in Zaria moved to Vom, which became the headquarters of the veterinary or animal health services for the whole country. More veterinary surgeons were recruited; and in addition to the production of sera and vaccines, training of auxiliary staff was established to produce village level workers to carry out vaccinations and to render first aid to sick animal. This training was upgraded as needs arose, and at its peak it produced 3 Nigerian registered veterinary surgeons in $\mathrm{co}$ operation with the old Yaba Higher College. Diagnostic services and research in connection with production and improvement of vaccines were initiated early at Vom. One can state with pride that the tissue culture rinderpest vaccine (TCRV) which made possible the control of cattle plague in many parts of Africa was developed at Vom. The National Veterinary Headquarters at Vom was decentralised in the early fifties following constitutional changes in the country and each state now has its own Veterinary Extension Services dealing mainly with control, prevention and treatment of livestock diseases. 
Another important establishment connected with animal health is the Nigerian Institute for Trypanosomiasis Research (NITR), an offshoot of WAITR, in Kaduna. Trypanosomiasis (Sleeping Sickness) affects human beings as well as animals, and is transmitted by tse tse flies which are cyclic vectors of the protozoal trypanosome. Animals suffering may abort if pregnant, or in the subacute or chronic form the animals may become emaciated, anaemic, poor doers or may die eventually. One of the major cons traints to the establishment of many cattle ranches in the southern states, despite their Derived savanna and Guinea savanna zones which have high cattle carrying potential, has been the scorge of tse-tse flies and trypanosomiasis. About $75 \%$ of the total land area of Nigeria is said to be infested with tse-tse flies. Happily, the Tse-tse and Trypanosomiasis Division (TTD) of the Federal Livestock Department has been able to reclaim several thousand hectares in the large Glossina Morsilans (tse-tse) belt both in the Northern and Southern States by aerial and ground spraying. Survey units of T.T.D. have carried out investigations into the density of glossina species in areas earmarked for ranching in the southern states, and a subcentre of the organization has been established at Ogoja. It is pro. posed to establish other centres at Umu. ahia, Ado-Ekiti, Benin and Port Harcourt during the Third National Development Plan period (FLD, 1975).

Research on susceptibility or otherwise of trypanosomes to chemotherapeutic agents continues to engage the attention of NITR and TTD.

The veterinary, public and animal health division of the Federal Livestock Department looks after veterinary preventive and state medicine at the federal level.
This brief background of institutions responsible for the advancement of animal health in the country will not be complete without giving recognition to animal diseases research being done at the veterinary schools of the Universities of Ahmadu Bello, Ibadan and Nsukka. Such important diseases as Kirchi (cutaneous streptothricosis), trypanosomiasis, brucellosis, caprine pneumonia enteritis complex $(\mathrm{Ka}$ ta) to mention a few, have been researched and reported on by these institutions.

\section{POPULATION OF DOMESTIC IIVESTOCK IN NIGERIA}

Uncontestable population figures of our livestock are not available since a thorough census has not been undertaken. However, the following figures (for 1974) are quoted from Vol. 1 of the Third National Development Plan (1975 80):

$\begin{array}{lr}\text { Cattle } & 8.5 \text { million } \\ \text { Goats } & 22.0 \text { million } \\ \text { Sheep } & 8.0 \text { million } \\ \text { Poultry - small scale - } 45.0 \text { million } \\ \text { Poultry - commercial-. } 5.0 \text { million } \\ \text { Pigs -- small scale }-0.45 \text { million } \\ \text { Pigs - commercial }-0.05 \text { million } \\ \text { Imported cattle }-0.28 \text { million } \\ \text { In } 1980 \text { it is proposed to raise the }\end{array}$
population figures thus - cattle 9.26 million; goats 24.30 million; sheep 8.80 million; poultry small scale 46.80 million; commercial 10.00 million; pigs, small scale 0.50 million; commercial, 0.10 million, but to decrease imported cattle to 0.14 million which means a population increase of $100 \%$ for commercial poultry and pigs. Also in terms of Naira the capital value of Nigeria's livestock is estimated at $\$ 2,700$ million, with gross output at producer prices $\$ 210$ million and retail prices at 390 million. At the end of the five year development plan in 1980, the total estimated expenditure on livestock 
development by the Federal Government and all the states together will be about \$344 million. Also during plan period, there is going to be a relocation/redistribution of the national herd, which in fact the drought of two years (1972 74) ago can be said to have initiated by movements of cattle herds from the far north towards the guinea savannah zone of the NigerBenue Basin. Grazing reserves are to be established, with necessary infrastructure, to induce the traditional nomadic Fulanis who own the bulk of Nigerian Cattle to move less. But equally important is the Federal Government of Nigeria and IBRD (World Bank) joint Beef Animals Development Project whereby 9 ranches will be established and technical support will be provided for 50 medium sized commercial ranches and 1,500 small holders. Four new ranches with an animal output of 32,500 cattle head will be established by Federal Institutions out of Federal Grants or financial resources. It is clear from the above that the traditional extensive system of livestock keeping will remain, but a bold attempt will be made to promote intensive rearing of poultry, pigs and trypanoresistant cattle to produce protein of animal origin which is needed to im. prove the diet of the fast growing population of Nigeria.

\section{POLICIES AND PROGRAMMES OF FEDERAL AND STATE GOVERNMENTS}

Let us examine next the Policies and Programmes of the Federal and the State Governments to combat health hazards associated with this giant stride to increase our livestock population and to bring about an improvement in our livestock production. The governments recognise the following as some of the constraints against improvement of livestock production in Nigeria: Animal diseases;
The presence of tse-tse fly which limits the grazing areas and reduces animal productivity;

Inadequate supply of feed/water during the dry season and

Lack of qualified manpower.

Relevant policy objectives aim at:

(a) eradication of tse-tse flies in feasible areas of the country:

(b) introduction of trypanotolerant breeds of cattle such as Muturu, Ndama and Keteku in the tse-tse infested areas;

(c) provision of adequate water supply in the semi-arid areas by drilling artesian wells and constructing dams;

(d) the production and utilization of protein rich concentrates:

(e) the encouragement of commercialized livestock farming by supplying infrastructural inputs and services such as disease control measures and

(f) encouragement of research in animal production and animal health.

The animal health programmes of the state governments during the plan period, include establishment of control posts, building of veterinary hospitals and clinics, initiation of veterinary meat inspection in more southern states (especially East Central) and setting up of vaccination centres. The Federal Livestock Department will also establish interstate control posts, quarantine stations in Ikeja, Apapa and at principal land entry points of livestock into the country to prevent the importation and spread of contagious diseases from overseas and from our neighbouring countries. As a temporary measure, the Federal Department of Veterinary Research has already posted two veterinary surgeons to the ports in Lagos in view of recent unpleasant events 
connected with an outbreak of African Horse Sickness in some imported horses.

As far as livestock research is concerned, the Federal Government will expand and improve facilities at FDVR and NITR and research effort; will be concentrated particularly on trypanosomiasis, contagious bovine pleuropneumonia (CBPP) and brucellosis. Research will be undertaken to improve vaccines production and to develop new vaccines. It is envisaged that a federal diagnostic and investigation laboratory will be built in each state. A Foot and Mouth Disease laboratory is likely to be built before 1980. An Animal Production Research Centre is being established at Zaria (attached to IAR). It is expected that research into reproductive diseases of livestock will be a part of its schedule of duties.

\section{SUGGESTED IMPROVEMENTS IN THE LIVESTOCK PROGRAMMES OF THE THIRD NATIONAL DEVELOPMENT PLAN}

These animal health programmes by the Federal and State Governments are laudable and should be commended. However, one should like to point out some areas which should have been given some more prominence or included in the programmes, and without which the targets desired may not be attained. Among such areas may be highlighted manpower training of animal health extension workers and veterinary specialists, legislations to enforce veterinary meat inspection throughout the Federation, initiation of a programme to tuberculin test every dairy animal producing milk for human or animal consumption, establishment of two subcentres of the Veterinary Research Centre, Vom; one to undertake research into poultry production and diseases and the other to deal with intensive production and diseases of sheep and goats; initiation. of research into wild life as reservoir of infective agents for domestic animals and establishment of a special programme of research on cutaneous streptothricosis (Kirchi] to find ways and means to control this disease which is a very serious cause of loss in cattle in Nigeria

The problem of shortage of graduate and auxiliary veterinary staff is quite obvious to all of us who have been associated with animal health services in this country. The establishment of 3 veterinary schools inthe country and the increase in number of intakes into them may parially solve this problem. As at the end of June, 1975, there were 350 registered veterinary surgeons in Nigeria. It is conservatively estimated that about 800 Nigerian veterinarians may be required by 1980 to give a semblance of satisfactory service to our livestock industry and population. This means that our veterinary schools will have to graduate at least 100 per year from 1976. Intensive system of keeping animals such as we wish to embark on brings along with it more complicated disease problems which may require specialist veterinarians to identify and deal with promptly to avoid great losses. The shortage of animal health assistant is a more acute problem. There are many Chief Veterinary Officers who have staff to train but can find no place to train them, even though the animal health assistant course was resuscitated in Vom in 1972. One suspects the lack of animal health assistants as one of the causes of vaccine wastage which has been noted in the field. Without adequate number of animal health assistants our disease control and preventive measures will be in jeopardy. It is envisaged, as an ideal, that every sizeable village or groups of villages should have a resident animal health 
entension worker. The new ranches will, of course, need them for vaccinations, deworming etc. Laboratories, clinics and control posts need adequately trained staff to man them or they will remain empty and of no use to anyone.

That veterinary inspection of meat is not enforced throughout Nigeria can be regarded as a serious lapse in our veterinary public health system. Anti mortem and postmortem inspection of animals by veterinarians allows for an accurate inventory of prevalent diseases in our national herds, and emerging diseases may be spotted early and appropriate actions taken promptly. Besides, a rich source of teaching materials for veterinary schools are being lost to health inspectors. Surely, by his training the veterinary surgeon is the best qualified to carry out quality meat inspection.

One of the common causes of carcase condemnation in slaughter houses in Nigeria is bovine tuberculosis. For example, 1,398 cases of bovine tuberculosis were recorded in the financial ycar 1973. 1974 in 7 slaughter houses where veterinarians were responsible for meat inspection, (FLD, 1974). The tubercule bacteria can be secreted in the milk and can be a source of infection to man and other animals especially where the milk is not sterilized before consumption. Condemnation of meat means loss of finished product, and a negative factor in improvement of livestock production. Effective means of control of bovine tuberculosis are available and should be applied to save human and animal lives and to reduce preventible loss of much needed animal protein.

A research centre for small domestic animals and poultry is desirable in view of the huge investment on them and because of the fact that they are a major source of increasing rapidly the supply of protein. The National Council for Agriculture and Natural Resources agreed in 1974 to the proposal for the establishment of zonal sub-centres to carry out livestock research appropriate to the ecological zones in which they are situated. For example, pneumonia of shesp and the 'pneumonia enteritis complex' of goats which have militated against herding or ranching of these animals require urgent research attention. It is hoped that the non-inclusion of the establishment of the subcentres is temporary and not permanent shelfing.

It may be disputed that research into wild life as a reservoir of infective agents for livestock is far fetched at this time. Judging from recent increases in the incidence of rabbies in dogs, cattle, sheep and pigs one is suspicious of wild-life as a factor in the transmission of the disease. The role of warthog in the transmission of trypanosomiasis and swine fever is well known. Many wild animals are also carriers of viruses and bacteria which are pathogenic to man and animals. Therefore, in a comprehensive veterinary public health and preventive medicine programme this type of research is essential and meaningful.

Following the successful J. P. 15 campaign to control and eradicate rinderpest and the recent launching (Feb. 1974) by the Head of State, General Yakubu Gowon, of the J. P. 28 campaign to control bovine pleuropneumonia, our most serious disease problem is bovine cutaneous streptothricosis (Kirchi). Research has been done and is still going on at Ahmadu Bello University, Ibadan University and Vom on the disease; we have not found the answer to the most effective treatment of the disease or its control. The disease is likely to assume major importance when the urban dairies 
which feature prominently in the 3rd Development Plan are established. Most of the dairies will consist of exotic breeds of cattle imported from abroad. Exotic breeds of cattle are, in our experience, more susceptible to and suffer higher mortality rate from Kirchi compared to local breeds. To make the urban dairies viable entities, concerted research efforts must be made to find some solution to the Kirchi problem. Beef animals, both indigenous and foreign cattle, are affected with Kirchi. Only Ndama and Muturu cattle are known to be resistant or tolerant to the disease. Besides mortalities and reduced weight gains, the hides of infected animals are not suitable for production of good quality leather. Millions of Naira may go down the drain if the disease remains unchecked. To protect the gigantic investment on our cattle population, it is suggested that a special Kirchi research fund be set up to help universities and research centres to concentrate on the disease and to meet the expenses of foreign experts who may be invited to join in the research programme.

In closing I would like to state that the old adage that "Health is wealth" applies equally to men and animals. If the factors that promote good health are well taken care of, we are assured of increased productivity and reasonable multiplication of our national herds.

\section{REFERENCES}

F.L.D. 1974. Federal Livestock Department, Report For January 1970 To March 1974.

F.L.D. 1975: Sixth Meeting of the National Council for Agriculture and Natural Resources, Kano 10th-13th July, 1975, Report by Director, Livestock Department.

MARSHALL, R.S. The Veterinary Department of Nigeria - its development from 1914-1955. (Federal Veterinary Research Library, Vom).

SANSI, K.A.O. 1974. Effect of Level and Quality of Protein on Bone of Growing Pigs. Ph.D. Thesis. Cornell University, Ithaca, Now York. 